5. Wynn T. A., Vannella K. M. Macrophages in Tissue Repair, Regeneration, and Fibrosis. Immunity. 2016;44(3):450462. https://doi.org/10.1016/j.immuni.2016.02.015

6. O'Sullivan J. A., Carroll D. J., Moreno-Vinasco L., Cao Y. Bochner B. S. [et al.] Frontline science: characterization of a novel mouse strain expressing human siglec-8 only on eosinophils. Journal of Leukocyte Biology. 2018;104(1):1119. https://doi.org/10.1002/JLB.2HI0917-391R

7. Platzer B., Singer K., Panduro M., Lexmond W. S., Fiebiger $E$. [et al.] Dendritic cell-bound ige functions to restrain allergic inflammation at mucosal sites. Mucosal Immunolo gy 2015:8(3):516-532. https://doi.org/10.1038/mi.2014.85

8. Sugimoto M. A., Ribeiro A. L. C., Costa B. R. C., Vago J. P., Lima K. M. [et al.] Phagocytes, granulocytes, \& myelopoiesis: Plasmin \& plasminogen induce macrophage reprogramming \& regulate key steps of inflammation resolution via annexin A1. Blood. 2017;129(21): 2896-2907. https://doi.org/10.1182/blood-2016-09-742825
9. Mosser D. M., Edwards J. P. Exploring the full spectrum of macrophage activation. Nature Reviews Immunology. 2008:8(12):958-969. https://doi.org/10.1038/nri2448

10. Breedveld A., van Egmond M., Kormelink T. G., de Jong E. C. Granulocytes as modulators of dendritic cell function. Journal of Leukocyte Biology. 2017;102(4):10031016. https://doi.org/10.1189/jlb.4MR0217-048RR

11. Uciechowski P., Rink L. Basophil, eosinophil, and neutrophil functions in the elderly. Immunology of Aging. 2014;10(1):47-63. https://doi.org/10.1007/978-3-642-39495-9 5

12. Cong Hong Hanh Khaziakhmetova $\mathrm{V}^{-} \mathrm{N}$ Ziganshina L. E. Modeling Inflammatory Edema: Are the Models Interchangeable? Experimental'naya i klinicheskaya pharmakologiya. - Experimetntal and Clinical Pharmacology. 2015;78(7):24-31.

13. Zimatkin S.M. Histology. Minsk, 2014

About authors:

Sirak Alla Grigorievna, MD, PhD, Professor, Head of Departament of histology; tel.: +78652356219; e-mail: kafedragist@yandex.ru

Piskareva Elena Ivanovna, MD, Associate Professor; tel.: +79887086717; e-mail: ivga.stgma@mail.ru

Magomedova Oksana Gasamutdinovna, Assistant; tel.: +79286319997; e-mail: oksana.magomedova@bk.ru

Arutjunova Alina Pavlovna, Assistant; tel.: +79881177100; e-mail: alina77100@gmail.com

Dolgashova Marina Aleksandrovna; MD, Associate Professor; tel.: +79054135520; e-mail: dolgashova@mail.ru

Didenko Maria Olegovna, postgraduate student; tel.: +79283406900; e-mail: dr.maria.didenko@gmail.com

Andriutsa Natalia Sergeevna, MD, Associate Professor of Departament of pathophysiology; tel.: +79161164747; e-mail: natiandriutsa@mail.ru

Kochkarova Zuchra Magomedovna, postgraduate student; tel.: +78652352628; e-mail: azrch_1991@rambler.ru

(C) Group of authors, 2019

UDC 616.71-089.844

DOI - https://doi.org/10.14300/mnnc.2019.14127

ISSN - 2073-8137

\title{
EXPERIMENTAL MODELING OF AURICULAR CARTILAGE ON ARTIFICIAL IMPLANTABLE MATRIX
}

Gaboyan A. N. ' , Sukorceva N. S. ${ }^{1}$, Aganesov G. A. ${ }^{1}$, Sinelnikov M. Y. ${ }^{3}$, Reshetov I. V. ${ }^{1}$, Nikolenko V. N. ${ }^{1}$, Kochurova E. V. ${ }^{1}$, Vorobyov A. A. ${ }^{2}$

${ }^{1}$ I. M. Sechenov First Moscow State Medical University (Sechenov University),

Russian Federation

2 Volgograd State Medical University, Russian Federation

${ }^{3}$ Institute for Regenerative Medicine, Sechenov University, Moscow, Russian Federation

\section{ЭКСПЕРИМЕНТААЬНОЕ МОАЕАИРОВАНИЕ РЕКОНСТРУКЦИИ УШНОГО ХРЯЩА НА ПОАИОЖКЕ}
А. Н. Габоян ${ }^{1}$,
Н. С. Сукорцева '
Г. А. Аганесов ${ }^{1}$
М. Е. Синельников ${ }^{3}$,

И. В. Решетов ${ }^{1}$,

1 Первый Московский госуАарственный меАицинский университет

им. И. М. Сеченова (Сеченовский Университет),

Москва, Российская Фелерация

2 ВолгограАсКий госУАарственнЫЙ МеАицинсКиЙ Университет, Российская ФеАерация

${ }^{3}$ Институт регенеративной меАицины Первого Московского ГосуАарственного МеАицинского Университета им. И. М. Сеченова (Сеченовский Университет), Российская ФеАерация

Reconstruction of cartilage tissue is an essential aspect of modern reconstructive surgery. This experimental study outlines the development and in vivo application of autologous cartilage tissue with flexible configuration with a Reperen on-lay mesh. As a result of the experiment, a novel method was developed for fixation of cartilage transplants in the recipient zone in a predetermined configuration. This allows for shape retention in the recipient zone during cartilage transplantation.

Keywords: cartilage autotransplantation, reperen, cartilage modeling, cartilage reconstruction, tissue reparation 
Реконструкция хрящевой ткани является актуальной проблемой в хирургии из-за частой потребности в восстановлении костно-хрящевых структур после хирургического вмешательства как с эстетической, так и с функциональной точки зрения. Проведена экспериментальная разработка метода фиксированного хрящевого аутотрансплантата заданной формы и конфигурации с помощью микрографтинга хрящевой ткани на эксплантируемой подложке. Экспериментальное моделирование гибридного хрящевого аутотрансплантата проведено на живой биологической модели (ушной хрящ кролика). В результате выполненного эксперимента отмечается стабилизация формы аутотрансплантата при фиксации на аллогенной синтетической подложке. Таким образом, создана модель биоинженерного хряща с сохранением трехмерной формы и конфигурации в реципиентном ложе с подложкой из реперена.

Ключевые слова: хрящевая аутотрансплантация, реперен, моделирование хряща, реконструкция хряща, репарация тканей

For citation: Gaboyan A. N., Sukorceva N. S., Aganesov G. A., Sinelnikov M. Y., Reshetov I. V., Nikolenko V. N., Kochurova E. V., Vorobyov A. A. EXPERIMENTAL MODELING OF AURICULAR CARTILAGE ON ARTIFICIAL IMPLANTABLE MATRIX. Medical News of North Caucasus. 2019;14(3):516-519. DOI - https://doi.org/10.14300/mnnc.2019.14127

Для цитирования: Габоян А. Н., Сукорцева Н. С., Аганесов Г. А., Синельников М. Е., Решетов И. В., Николенко В. Н., Кочурова Е. В., Воробьев А. А. ЭКСПЕРИМЕНТАЛЬНОЕ МОДЕЛИРОВАНИЕ РЕКОНСТРУКЦИИ УШНОГО ХРЯЩА НА ПОДЛОЖКЕ. Медицинский вестник Северного Кавказа. 2019;14(3):516-519. DOI - https://doi.org/10.14300/mnnc.2019.14127

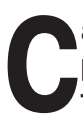
artilage tissue is often used in reconstructive and plastic surgery for correction of aesthetic and functional defects. The history of cartilage tissue reconstruction can be tied to the first documented attempt to reconstruct the auricular cartilage by Gillies in 1920. Gillies attempted to correct microtia via allogeneous rib cartilage transplantation [1]. Despite aesthetically valid results, allogenenous cartilage was unstable and would succumb to complete resorption [2]. Authors Young and Peer in the early 1940s performed autologous cartilage transfer. Due to high instability of transplants, they placed the cartilage into a metallic structure, which was later implanted into the anterior abdominal wall. After 5 months, the prefabricated cartilage was removed and transplanted into the recipient zone. Significant retention of required shape was noted [3]. Currently there is no unified method of autologous cartilage transfer in a fixed configuration.

The use of heavy structures for cartilage fixation often leads to extrusion, due to skin ulceration over the prosthesis and consequent suppuration [4]. Lighter silicone implants for cartilage tissue reconstruction proved to be extremely weak, and couldn't withstand minimal traumatization. These implants had to be explanted after surgical procedure at various terms [5, 6]. Non-organic implants for cartilage reconstructive can be popularized with development of sturdy biocompatible materials, which can be printed via 3D-printing technology [7]. These printed implantable structures are fixed to bones in the recipient zone [8].

The most acceptable approach to cartilage reconstruction lies in the combination of $3 \mathrm{D}$ modifiable structuring and autologous cartilage transfer. This can be achieved by implementing the bioengineering method, which consists of cartilage configuration and implantation with viability support and structural consistency [9]. Our experimental study was focused on development of an acceptable bioengineered method of autologous cartilage reconstruction with a predetermined, modifiable and consistent from.

Material and Methods. This work was approved by the local ethics committee at Sechenov University. The experiment was carried out in accordance with the ethical standards of the Sechenov University institutional ethics committee and with accordance to ARRIVE and National Guidelines.

The experimental development of autologous cartilage transplant fixation of given parameter and size was conducted. After theoretical modeling of this method, experimental subcutaneous implantation of cartilage autotransplant with stability monitoring was performed in vivo.

The material «Reperen» was used for developed of bioengineered implantable composite structure. Reperen was chosen due to sustainable inertness, low heat conductivity, modifiable configuration and stability. The later is necessary to modify the configuration of cartilage placed on the material, and is achieved by heating of Reperen. Reperen proved to be stable after configuration modification, inert to mechanical and chemical influence of organic tissue.

The study included two groups of rabbits, 15 subjects in each group. Group A (control) included 15 rabbits, which received implantation of autologous cartilage tissue without modeling. Group B (experimental group) included 15 rabbits, who received implantation of modeled autologous cartilage tissue in complex with configured Reperen mesh. In each group, all the subjects received implantation of transplant subcutaneously on the interior surface of the auricle. The Reperen mesh was modified prior to implantation.

An autologous cartilage graft in rabbits from Group A was excised from the right ear in all cases, with consequent dicing into $0.1 \mathrm{~cm} \times 0.1 \mathrm{~cm}$ pieces and subperichonreal replantation into the left ear in the form of a cylinder with a diameter of $0.5 \mathrm{~cm}$ and size of $0.5 \times 0.3 \mathrm{~cm}$ (Fig. 1). Rabbits from Group B underwent similar excision of cartilage from the right ear, after which the explanted tissue was prepared and micrografts were aquired. The creation of micrografts was performed via dicing of cartilage and removing excess tissue fragments [10]. The cartilage micrografts were placed onto a Reperen mesh, which was previously modified to sustain a cylindrical form. The combined structure was $0.55 \mathrm{~cm} \times 3.0 \mathrm{~cm}$ in size. The composite Reperen-Cartilage structure was implanted subperichondreally into the left ear (Fig. 2). The extraction of the structures was performed 45 days after implantation. Histological evaluation of transplants was performed in each case. 


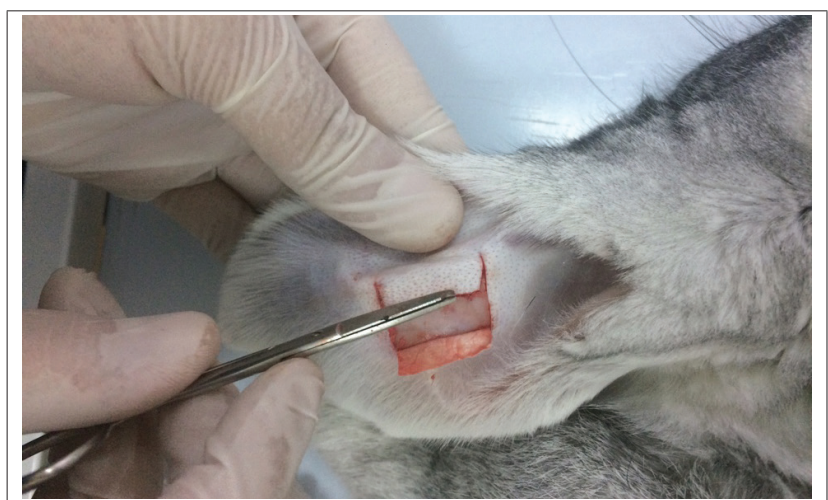

A

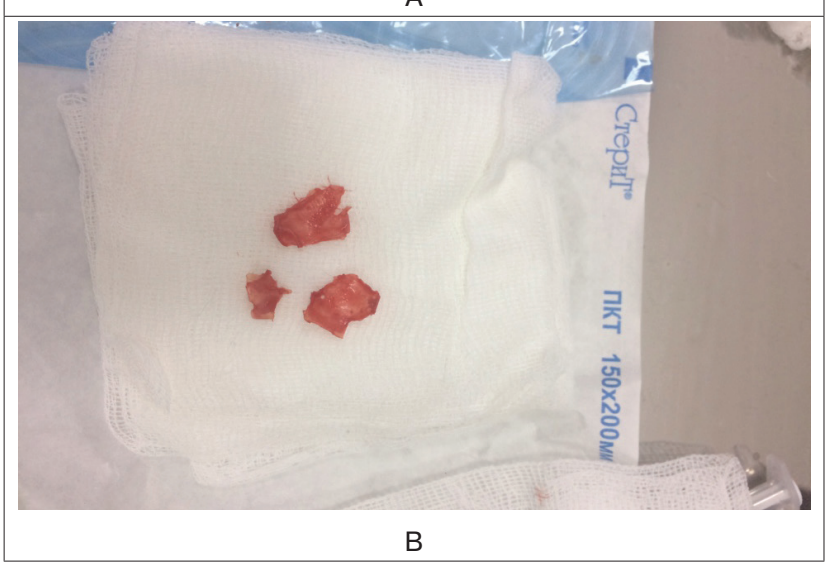

Fig. 1. The stage of experimental work: A - harvesting of cartilage for replantation; B - prepared autologous cartilage autotransplant

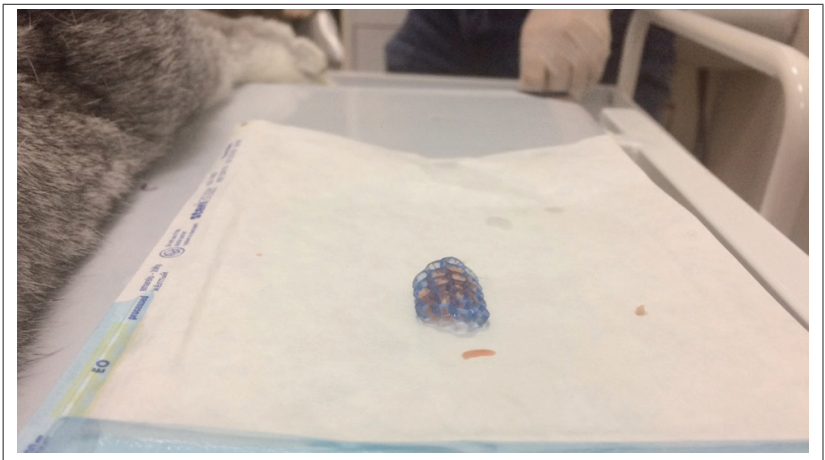

A

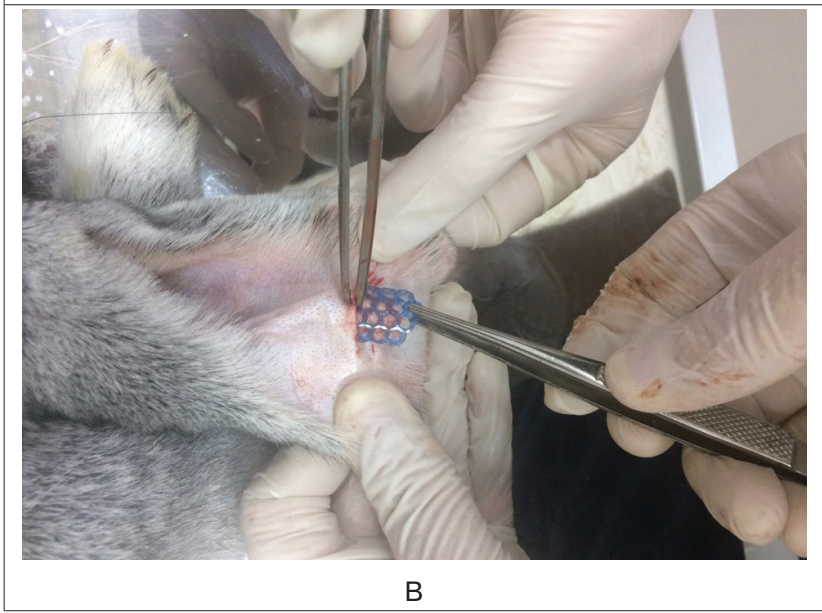

Fig. 2. The stage of experimental work: A - prepared

for replantation autologous cartilage tissue on a matrix; $B$ - replantation of bioengineered Reperen-cartilage complex
Results and Discussion. No infection related complication were noted in either group. The implant in Group A did not retain cylindrical from in any of the cases (15 subjects - $100 \%$ ). Implants (Reperen-cartilage complex) in group B retained cylindrical form in all cases (15 subjects - $100 \%$ ). Morphological evaluation of components was performed on the 14th and 21st days after implantation. Staining was performed by hematoxylin-eosin and Van-Gieson stain. Inflammatory response was absent in all cases. The results of histologic examination showed biocompatibility of the selected material (Reperen) for creation of a hybrid implantable complex (Fig. 3). The results suggest that the given method is effective and safe. It is our conclusion that Reperen-cartilage composite implants can be implemented in clinical practice for reconstruction of cartilage tissue.

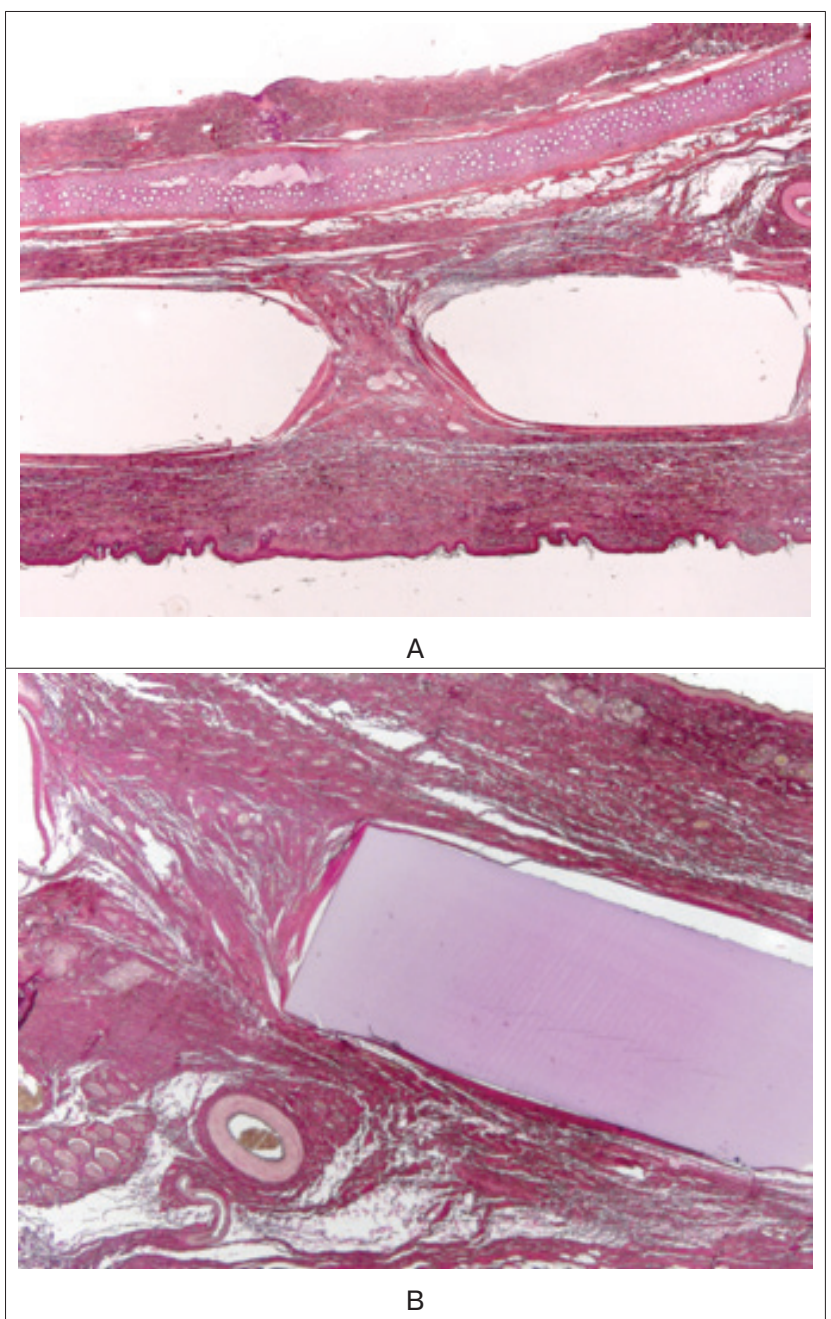

Fig. 3. Morphological investigation: A - tissue of habit ear are seen: epidermis, derma, cartilage and implant is visualized as two oval structures, separated by connective tissue, hematoxy-

lin \& eosin stain, zoom x25; B - implant is visualized of lightviolet color, surrounded by connective tissue capsule of bright-red color, Van-Giesonstain, zoom x40

As a result of the experimental study, a functional analysis and development of a bioengineered Reperencartilage complex was achieved. Based on knowledge of biochemical stabilityand compatibility of Reperen implants [11], analysis of the developed bioengineered structure with Reperen as a matrix was possible. The attributes of Reperen make it possible for application in complex reconstruction of cartilage tissue defects $[12,13]$. 
Modern progress in composite materials development is due to increased studies on bioengineered components [14]. The next stage in cartilage tissue replantation is currently considered to be decellularzation of transplants $[15,16]$. Yet even decellularized tissue structures require fixation in the recipient zone for shape retention. This can be achieved with biocomposite matrixes, such as Reperen [17].

Conclusions. The developed method of bioengineered composite structure development for reconstruction of cartilage tissue is deemed successful. As a result of the experimental work, systematic analysis of literature, and experience in clinical practice, Reperen proves to be a biocompatible, inert material, which can be used for reconstructive purposes for modeling and fixation of cartilage tissue. Biofunctional characteristics of Reperen represent the safety in application of the exogenous material with lack of response from recipient organism immune system. Significant research into the clinical use of Reperen [18, 19, 20] shows the expediency of clinical application. Reperen has a low contamination potential, the material does not change size or form, it is inert. In the course of an in vivo experiment, a model for bioengineered cartilage structure of given threedimensional configuration is developed with Reperen used as a matrix for cartilage stability.

\section{Disclosures:}

The authors declare no conflict of interest.

\section{References}

1. Gillies H. D., Pilcher L. S. Plastic Surgery of the Face. Annals of Surgery. 1920;72(6):766

https://doi.org/10.1097/00000658-192012000-00015

2. Converse J. M. LXXII Corrective Surgery of the Nasal Tip. Annals of Otology, Rhinology \& Laryngology. 1940;49(4):895911. https://doi.org/10.1177/000348944004900402

3. Young F. Cast and precast cartilage grafts. Surgery. 1944;15(1):735. https://doi.org/10.1097/00006534-194707000-00016

4. Cronin T. D., Greenberg R. L., Brauer R. O. Follow-up study of silastic frame for reconstruction of external ear. Plastic and reconstructive surgery. 1968;42(6):522-529. https://doi.org/10.1097/00006534-196812000-00002

5. Monroe C. W. Our experiences with the silicone ear framework: A report of 17 ears in 15 patients. Plastic and reconstructive surgery. 1972;49(4):428-432. https://doi.org/10.1097/00006534-197204000-00012

6. Vodianickiy V. B. Correction and prophylactics of complications in microtia treatment in children. Annali plasticheskoy rekonstruktivnoy i esteticheskoy hirurgii. 2008;1(1):39.

7. Vodianickiy V. B. Earlobe reconstruction in children (expectation and reality). Annali plasticheskoy rekonstruktivnoy i esteticheskoy hirurgii. 2006;1(4):60.

8. Kruchinskiy G. B., Nerobeev A. I. Correction of earlobe defects. Reconstructive surgery of the soft tissues of the maxillofacial area. Moscow: Meditsina Publ.; 1997:136-155.

9. CaoY., Vacanti J. P., Paige K. T. Transplantation of chondrocytes utilizing a polymer-cell construct to produce tissue-engineered cartilage in the shape of human ear. Plastic and reconstructive surgery. 1997:100(2):297-302. https://doi.org/10.1097/00006534-199708000-00001

10. Reshetov I. V. Patent № 2016137499/20 (059160) «Methods of reconstruction of organs and tissues». Official bulletin of the Federal service for intellectual property (Rospatent) «Innovations. Useful models» № 9-2018, 21.03.2018-27.03.2018

11. Tihomirov S. E., Cibusov S. N., Kravex L. I. The study of the reaction of soft tissue to implantation of the polymer «Reperen». Neriohirurgiya. 2012;1(3):45-52.

12. Treushnikov V. M., Viktorova E. A. Basics of creating biocompatible and biostable polymer implants (review). Sovremenniye technologii v medicine. 2015;7(3):149-171.

13. Tikhomirov S. E. Application of reperenminiplate for minor calvarium defect plasty in intracerebral hematoma removal. Sovremenniye technologii v medicine. 2015;7(2):198-201. https://doi.org/10.17691/stm2015.7.2.23

14. Faust H. J., Guo Q., Elisseeff J. H. Cartilage Tissue Engineering. Principles of Regenerative Medicine. 2019:937-952.

https://doi.org/10.1016/b978-0-12-809880-6.00053-9

15. Nayyer L., Jell G., Esmaeili A., Birchall M., Seifalian A. M. A biodesigned nanocomposite biomaterial for auricular cartilage reconstruction. Advanced healthcare materials. 2016;5(10):1203-1212

https://doi.org/10.1002/adhm.201500968

16. ChenY. C., Chen R. N., Jhan H. J., Liu D. Z., Ho H. O. [et al.] Development and characterization of acellular extracellular matrix scaffolds from porcine menisci for use in cartilage tissue engineering. Tissue Engineering Part C: Methods. 2015;21(9):971-986.

https://doi.org/10.1089/ten.tec.2015.0036

17. Rowland C. R., Colucci L. A., Guilak F. Fabrication of anatomically-shaped cartilage constructs using decellularized cartilage-derived matrix scaffolds. Biomaterials. 2016;91:57-72.

https://doi.org/10.1016/j.biomaterials.2016.03.012

18. Danilova D. A., Gorbunova L. I., Tsybusov S. N., Uspensky I. V., Kravets L. Y. Materials for Plastic Surgery of the Dura Mater: History and Current State of the Problem (Review). Sovremennye Tehnologii $v$ Medicine. 2018;10(3):194

https://doi.org/10.17691/stm2018.10.3.24

19. Ryabova D. A., Orlinskaya N. Y., Tsybusov S. N., Homutinnikova N. E., Lapshin R. D. [et al.] Application of Polymer Phospholipid Matrix for Closing Open Wounds on Oral Mucosa. Sovremennye Tehnologii v Medicine. 2016;8(1):5563. https://doi.org/10.17691/stm2016.8.1.08

20. Slovikov S. V. Mechanical properties of mesh implants used in the repair of hernia defects of the anterior abdominal wall. Proceedings of the X All-Russian Conference on the Mechanics of Deformable Solids. Samara: SSThUPubl., 2017.

\section{About authors:}

Gaboyan Arthur Nersesovich, postgraduate; tel.: +79171832635; e-mail: dr_gaboyan@mail.ru

Sukorceva Natalya Sergeyevna, MD, Head of the Department of oncology; tel.: +79168313004; e-mail: sukorceva.nataly@mail.ru

Aganesov Georgy Aleksanrovich, MD, Assistant of Professor of the Department of oncology,

plastic \& reconstructive surgery and radiology; tel.:+79262353078; e-mail: aganesov@mail.ru

Sinelnikov Mikhail Yegorovich, MD, Junior Scientist of the Department of oncology, plastic \& reconstructive surgery and radiology; tel.: +79199688587; e-mail: Mikhail.y.sinelnikov@gmail.com

Reshetov Igor Vladimirovish, MD, PhD, Academician of the Russian Academy of Sciences, Director of the Department of oncology, plastic \& reconstructive surgery and radiology; tel.: +74959458723; e-mail: reshetoviv@mail.ru

Nikolenko Vladimir Nikolaevich, MD, PhD, Professor, Head of the Department of normal anatomy; tel.: +79647751134; e-mail: vn.nikolenko@yandex.ru

Kochurova Ekaterina Vladimirovna, MD, PhD, Professor of the Department of prosthetic dentistry; tel.: +79265113801; e-mail: evkochurova@mail.ru

Vorobyov Aleksandr Aleksandrovich, MD, PhD, Head of the Department of operative surgery and topographic anatomy; tel.: +79093806613; e-mail: Cos@volgmed.ru 